\title{
UJI KANDUNGAN PROTEIN FORMULASI KERANG/KOTENG (Pilsbryoconcha exilis) MENJADI MP-ASI DI DESA LAMASI PANTAI
}

\author{
Dian Furqani Hamdan ${ }^{1)^{*}}$ dan Mardiana ${ }^{2)}$ \\ ${ }^{1,2)}$ STIKES Bhakti Pertiwi Luwu Raya \\ *email : dianfurqanihamdan@gmail.com
}

\begin{abstract}
Based on RISKESDAS data on the amount of stunting in children under five in Indonesia, this study conducted a test of the nutritional content of protein in local foodstuffs of the coastal Lamasi village community, namely Koteng mussels (Pilsbryoconcha exilis). This is to support the government of South Sulawesi to reduce the prevalence rate of stunting (very short and short) who experience malnutrition and malnutrition. This study only focuses on testing the protein content as the main substance and nutrition for the growth and development of toddlers, while the method used in this study is the shellfish formulation which is done manually where the raw material is boiled and dried then smashed into powder and then tested for protein content using the Kjeldahl method in the Sucofindo laboratory weighing 500 grams. The results of the protein content test of the formulation of Koteng shellfish (P.exilis) resulted in a protein content of $56.66 \%$. As for the preparation of MP-ASI recipes with a collection of river clams worth $70 \mathrm{~g}, 4 \mathrm{~g}$ skim milk, $6 \mathrm{~g}$ rice flour, and $2 \mathrm{~g}$ vegetable oil, each containing protein worth 7,9\% successively $6,5 \% ; 9,6 \% ; 2 \%$
\end{abstract}

Keywords: koteng shells (Pilsbryoconcha exilis), MP-ASI, stunting

\section{PENDAHULUAN}

Makanan Pendamping Air Susu Ibu (MP-ASI) adalah makanan tambahan yang diberikan kepada bayi setelah usia 6-26 bulan guna untuk memenuhi kebutuhan gizi. Namun, pemeberian MP-ASI yang tidak sesuai akan menjadi salah satu penyebab meningkatnya prevalensi kekurangan gizi pada anak usia 12-24 bulan di dunia maupun di Indonesia.

$$
\text { Pemberian MP-ASI dilakukan }
$$

dengan wawancara menggunakan

kuesioner. Status gizi dinilai secara antropometri menggunakan indikator Berat Badan (BB) berdasarkan Panjang Badan $(\mathrm{BB} / \mathrm{PB})$ dan $\mathrm{BB}$ berdasarkan umur $(\mathrm{BB} / \mathrm{U})$, baby scale dan length board. (Wargiana, 2013). Desa Iloheluma merupakan salah satu desa yang menjadi prioritas penanganan stunting tahun 2019.
Intervensi stunting dapat dilakukan melalui pemanfaatan pangan lokal menggunakan sumber protein dan zink seperti kerang. Alternatif yang lain dengan meningkatkan pengetahuan masyarakat tentang potensi dan hasil dari olahan pangan lokal yang dapat dimanfaatkan dalam pencegahan dan penanggulangan stunting.

Kerang/kijingsungai (Pilsbryoconcha exilis) mengandung logam berat $\mathrm{Hg}$ dan Mn yang dianalisis menggunakan Spektrofometer Serapan Atom (SSA) yang dilakukan di laboratorium kimia analitik Universitas Mataram menunjukkan bahwa spesies yang tertinggi pun terdapat pada stasiun 3 dengan nilai $38,52 \mathrm{mg} / \mathrm{kg}$ dan yang terendah terdapat pada stasiun 1 dengan nilai $12,9 \mathrm{mg} / \mathrm{kg}$. Rata-rata kandungan $\mathrm{Hg}$ dan $\mathrm{Mn}$ tertinggi yang terdapat pada stasiun 3 dengan nilai 
masing-masing 1,9 mg/kg dan 234,46 $\mathrm{mg} / \mathrm{kg}$. Nilai $\mathrm{Hg}$ dan $\mathrm{Mn}$ terendah terdapat pada stasiun 1 dengan nilai $\mathrm{Hg} 0,025$ $\mathrm{mg} / \mathrm{kg}$ dan $150,77 \mathrm{mg} / \mathrm{kg}$ untuk Mn (Filsa dkk, 2017)

Bayi yang gagal tumbuh banyak terjadi pada bulan ketiga atau keempat awal kehidupan. Pemberian MP-ASI dini mengakibatkan ibu tidak berusaha memberi ASI dan menyebabkan terjadinya penyakit infeksi yang mengakibatkan stunting pada balita. Berdasarkan penelitian pada bayi usia 4-7 bulan di Kecamatan Ratu Samban-Bengkulu dengan menggunakan observasional analitik, desain cross sectional dan 4 KTI STIKES Bhakti Pertiwi Luwu Raya menunjukkan status gizi berdasarkan indeks $\mathrm{PB} / \mathrm{U}$ kategori pendek 12,3\% dan MP-ASI dini 66,7\% (Hasan, 2019).

Di Provinsi Sulawesi Selatan pada tahun 2013 terdapat prevalensi balita stunting (sangat pendek dan pendek) sebesar $40 \%$ dan mengalami penurunan menjadi $38 \%$ pada tahun 2018. Selain itu,juga terdapat balita yang mengalami status gizi kurang dan gizi buruk pada tahun 2013 sebesar 28\% dan mengalami penurunan menjadi 25\%. Walaupun mengalami penurunan tetapi prevalensi balita di suatu wilayah jika kurang dari $20 \%$ dikategorikan baik, bila prevalensi balita pendek lebih dari 20\%. Jadi dapat disimpulkan bahwa di provinsi Sulawesi Selatan terdapat balita stunting menurut Hasil Riskesdas 2018.

Studi Observasi awal yang dilakukan di Desa Lamasi Pantai pada Bulan Februari tahun 2020, status gizi balita berdasarkan Indeks $\mathrm{TB} / \mathrm{U}$ terdapat prevalensi balita stunting (sangat pendek dan Pendek) secara berturut turut yaitu $16 \%$ dan $16 \%$ sedangkan menurut indeks $\mathrm{BB} / \mathrm{U}$ prevalensi balita gizi buruk dan gizi kurang secara berturut-turut yaitu $2 \%$ dan $6 \%$. Sementara menurut indeks BB/TB prevalensi balita sangat kurus dan kurus secara berturut-turut yaitu 4\% dan 13\%. Selain itu jumlah posyandu di Desa Lamasi Pantai yaitu sebanyak 18 posyandu.

\section{METODE PENELITIAN}

\section{a. Jenis Penelitian}

Jenis penelitian ini adalah eksperimental laboratorium yaitu membuat formulasi kerang menjadi resep MP-ASI dari bahan lokal kerang sungai (koteng) untuk bubur bayi.

\section{b. Waktu dan Tempat Penelitian}

1. Waktu

Lama waktu penelitian 1 bulan dari awal pembuatan formulasi kerang koteng hingga pengujian kandungan bahan.

\section{Tempat}

Penelitian dilakukan di laboratorium STIKES Bhakti Pertiwi Luwu Raya dan pengujian sampel dilakukan di laboratorium Sucofindo.

\section{c. Populasi dan Sampel}

1. Populasi

Kerang sungai yang oleh masyarakat Desa Lamasi Pantai disebut koteng

2. Sampel kerang sungai sebanyak 500 gram. 


\section{d. Prosedur Kerja}

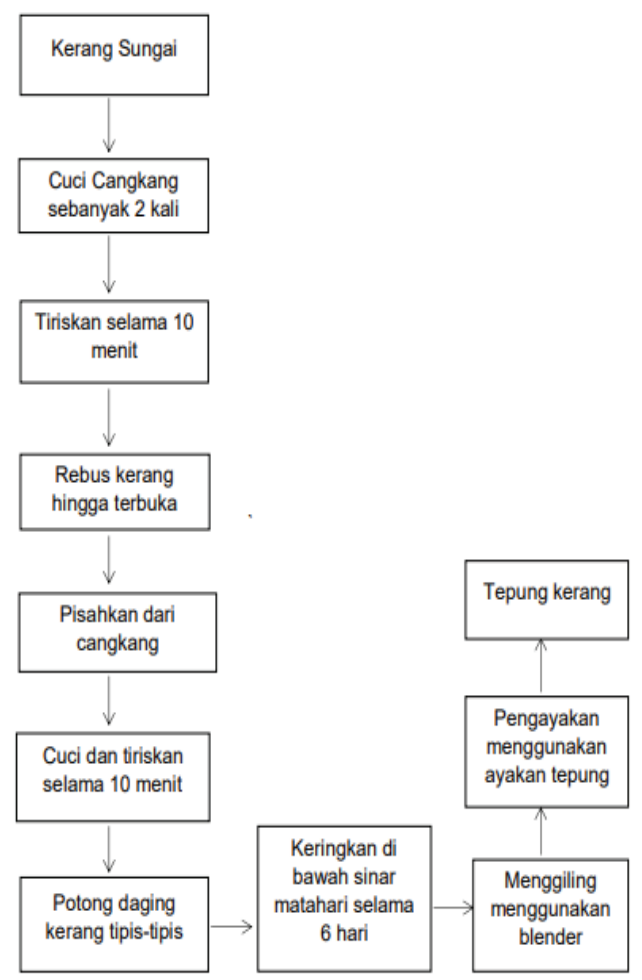

Gambar 1. Prosedur kerja

\section{HASIL DAN PEMBAHASAN}

Hasil dari penelitian ini adalah formulasi tepung kerang (P.exilis) dengan uji protein yaitu membuat resep MP-ASI dari tepung kerang yang diuji di laboratorium sucofindo dengan penjelasan berikut ini.

Tipe sampel : Tepung kerang

Deskripsi sampel: Packing Cup

Berat :500 gram.

Tabel 1. Hasil pengujian tepung kerang

\begin{tabular}{llll}
\hline Parameter & Unit & Hasil & Metode \\
\hline Protein & $\%$ & 56,66 & Kjeldahl \\
\hline
\end{tabular}

Metode Kjeldahl adalah analisis protein dalam bahan pangan. Analisis dapat dilakukan dengan dua metode yaitu metode kuantitatif dan kualitatif. Kadar protein yang ditentukan berdasarkan cara Kjeldahl disebut sebagai kadar protein kasar (crude protein) karena terikat senyawaan $\mathrm{N}$ bukan protein. Prinsip kerja dari metode Kjeldahl adalah protein dan komponen organik dalam sampel didestruksi dengan menggunakan asam sulfat. Hasil destruksi dinetralkan dengan menggunakan larutan alkali melalui destilasi. Destilat ditampung dalam larutan asam borat. Selanjutnya ion- ion borat yang terbentuk dititrasi dengan menggunakan larutan $\mathrm{HCl}$.

Kebutuhan protein untuk bayi setiap usia pun berbeda. Dari tabel pembuatan resep di atas untuk bayi usia 12-24 bulan kebutuhan protein yang harus dipenuhi untuk kecukupan gizi adalah 26\%, maka di buat resep MP-ASI dengan komposisi 82 gram sehingga dapat diuraikan jumlah tepung kerang sebanyak 70 gram mengandung protein dengan persentase $7,9 \%$; susu skim dengan berat 4 gram mengandung protein $6,5 \%$; tepung beras dengan berat 6 gram mengandung protein dengan persentase $9,6 \%$ dan minyak nabati dengan berat 2 gram mengandung protein dengan persentase $(2 \%)$.

Tabel 2. Resep MP-ASI

\begin{tabular}{lcc}
\hline Nama Bahan & $\begin{array}{c}\text { Jumlah } \\
(\mathbf{g})\end{array}$ & $\begin{array}{c}\text { Persentase } \\
(\mathbf{\%})\end{array}$ \\
\hline Tepung Kerang & 70 & 7,9 \\
Susu Skim & 4 & 6,5 \\
Tepung Terigu & 6 & 9,6 \\
Minyak Nabati & 2 & 2,0 \\
\hline
\end{tabular}

Manfaat MP-ASI adalah untuk memenuhi kebutuhan gizi anak usia 12-24 bulan agar mencapai pertumbuhan dan perkembangan yang optimal. Bayi tidak hanya membutuhkan Air Susu Ibu (ASI), melainkan juga makanan pendamping ASI sebagai pendukung untuk menambah 
asupan nutrisi guna menunjang fase tumbuh kembangnya.

MP-ASI yang diberikan sebelum usia 4 bulan diklasifikasikan sebagai MPASI dini, sedangkan bila diberikan setelah usia 6 bulan diklasifikasikan sebagai MPASI terlambat. Usia 6-9 bulan adalah masa kritis untuk mengenalkan makanan padat secara bertahap sebagai stimulasi keterampilan oromotor. Jika pada usia di atas 9 bulan belum pernah dikenalkan makanan padat, maka kemungkinan untuk mengalami masalah makan di usia batita meningkat. Oleh karena itu konsistensi makanan yang diberikan sebaiknya ditingkatkan seiring bertambahnya usia (IDAI, 2015). Pola makan pada balita sangat berperan penting dalam proses pertumbuhan pada balita karena dalam makanan banyak mengandung gizi. Gizi menjadi bagian yang sangat penting dalam pertumbuhan.

Gizi di dalamnya memiliki keterkaitan yang sangat erat hubungannya dengan kesehatan dan kecerdasan. Jika pola makan tidak tercapai dengan baik pada balita maka pertumbuhan balita akan terganggu, tubuh kurus, pendek bahkan bisa terjadi gizi buruk pada balita. Kerang mutiara muda dapat dibudidayakan di dalam tabung penampungan di dalam laboratorium. Sumber makanan diperoleh melalui bantuan campur tangan manusia, dimana setiap harinya dikondisikan pemberian makan berupa plankton yang telah di kultur masal di dalam laboratorium. (Eric H, 2018)

Kijing ini menyukai perairan yang dalam dengan kecerahan yang tinggi, mengandung Bahan Organik Total (BOT) yang tinggi dan substrat liat atau berlumpur. Pada habitatnya, kerang mempunyai pola distribusi memencar dengan populasi berkelompok. Beberapa faktor lingkungan yang mempengaruhi kehidupan dari kerang yaitu suhu, $\mathrm{pH}$, endapan lumpur dan fluktuasi permukaan air (Hendris, 2017).

Hasil penelitian uji kandungan protein formulasi kerang yang dilakukan di Laboratoriun Sucofindo dengan berat 500 gram tepung kerang menghasilkan kandungan protein dengan persentase $56,66 \%$ yang di uji dengan metode Kjeldahl. Hasil penelitian yang dilakukan oleh Asadatun Abdullah pada tahun 2017, terhadap kerang tahu dan kerang salju yang menggunakan metode Kjeldahl menunjukkan kandungan protein secara berturut-turut $\quad 9,39 \%$ dan $11,37 \%$. Berdasarkan penelitian yang dilakukan oleh Henni Rosaini pada tahun 2015 terhadap kadar protein pada kerang remis segar, kerang remis gulai dan kerang remis goreng dengan menggunakan metode Kjeldahl melalui tahapan destruksi, destilasi dan titrasi. Masing-masing sampel didestruksi dengan menggunakan asam sulfat pekat dan katalisator campuran selenium. Hasil destruksi ditambahkan natrium hidroksida untuk membebaskan amonia kemudian didestilasi ke dalam larutan yang berisi asam klorida. Kemudian larutan asam klorida dititrasi dengan natrium hidroksida $0,1 \mathrm{~N}$ yang ditetesi indikator metil merah. Kadar protein dapat dihitung dengan mengalikan kadar nitrogen total dengan faktor konversi (nitrogen total $\times 6,25$ ). Kadar protein yang paling tinggi yaitu kadar protein kerang remis goreng $7,1491 \% \pm 0,0249$.

\section{SIMPULAN}

\section{A. Simpulan}

Berdasarkan hasil penelitian dapat disimpulkan bahwa hasil penelitian uji 
kandungan protein formulasi kerang (koteng) yang dilakukan di Laboratorium Sucofindo dengan berat 500 gram tepung kerang menghasilkan kandungan protein dengan persentase $56,66 \%$. Dari penelitian ini didapatkan bahwa kerang dapat dimanfaatkan sebagai bahan baku dalam pembuatan MP-ASI. Analisis protein dalam bahan pangan dapat dilakukan dengan dua metode yaitu metode kuantitatif yaitu kadar protein yang ditentukan berdasarkan cara Kjeldahl yang disebut sebagai kadar protein kasar (crude protein) dan kualitatif berdasarkan kandungan gizi yang dibutuhkan balita.

\section{B. Saran}

1. Penelitian selanjutnya diperlukan adanya penelitian terhadap formulasi bubur bayi menjadi bubuk bayi instan agar mempermudah konsumen dalam penyeduhan menjadi bubur bayi.

2. Perlu adanya penelitian lebih lanjut mengenai stabilitas penyimpanan, anti bakteriologi dan alergisitas

\section{DAFTAR PUSTAKA}

Rosaini, H., Rasyid, R., \& Hagramida, V. (2017). Penetapan kadar protein secara kjeldahl beberapa makanan olahan kerang remis (corbiculla moltkiana prime.) dari Danau Singkarak. Jurnal Farmasi Higea, 7(2), 120-127.

Wulandari, Anindita, Sri Martuti, and Pudjiastuti Kaswadi. "Perkembangan diagnosis sepsis pada anak." Sari Pediatri 19.4 (2018): 237-44.

Nendris, Sulistiawan R. Selfi. "Potensi kijing (Pilsbryoconcha exilis) sebagai biofilter perairan di Waduk Cirata, Kabupaten Cianjur, Jawa
Barat." Skripsi. Departemen Manajemen Sumberdaya Perairan, Fakultas Perikanan dan Ilmu Kelautan, Institut Pertanian Bogor: Bogor (2007).

Abdullah, Asadatun, Taufik Hidayat, And Rizky Chairunisah. "KARAKTERISTIK KIMIAWI DARI DAGING KERANG TAHU, KERANG SALJU DAN KEONG MACAN." Journal of Food Technology \& Industry/Jurnal Teknologi \& Industri Pangan 28.1 (2017).

Rosaini, Henni, Roslinda Rasyid, and Vinda Hagramida. "Penetapan kadar protein secara kjeldahl beberapa makanan olahan kerang remis (corbiculla moltkiana prime.) dari Danau Singkarak." Jurnal Farmasi Higea 7.2 (2017): 120127.

Hasan, A., \& Kadarusman, H. (2019). Akses ke Sarana Sanitasi Dasar sebagai Faktor Risiko Kejadian Stunting pada Balita Usia 6-59 Bulan. Jurnal Kesehatan, 10(3), 413-421.

Alkautsar, Wildan. Pengaruh faktor oseanografi terhadap laju penempelan macrofouling pada tiang pancang jembatan Suramadu. Diss. UIN Sunan Ampel Surabaya, 2020.

Wargiana, Risa, Latifa Aini Susumaningrum, and Iis Rahmawati. "Hubungan Pemberian MP-ASI Dini dengan Status Gizi Bayi Umur 0-6 Bulan di Wilayah Kerja Puskesmas Rowotengah Kabupaten Jember." Pustaka Kesehatan 1.1 (2013): 47-53. 